\title{
東京大学 高齢社会総合研究機構
}

\author{
飯島 勝矢
}

（日老医誌 $2019 ； 56 ： 532-536$ )

我が国は世界の他のどの国も経験した事のない超高齢

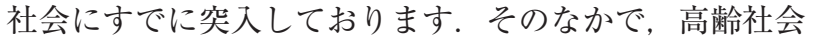
問題に関する分野横断的 ·体系的 - 実践的 ·協創的 - 国 際的な研究教育・社会連携活動を推進しております。そ して, 国際的な産官学民連携体制の下, 分野横断的研究 チームによる社会実験的フィールドスタディ（アクショ ン・リサーチ）を地域や活動の現場で推進することを通 じて, 活力ある超高齢社会を実現する実効的な施策を構 想・提案・社会実装・普及することを活動の中軸として おります。すなわち，継続性のある(サステナブルな), 多世代交流も進んだ高齢社会対応のまちづくりを地域で 実践しております。そこで, 今回, 筆者の所属する組織 を紹介したいと思います。

東京大学は複数の学部を持ち合わせる, いわゆる総合 大学であることから，その強みを活かし，2006 年に東 京大学総括プロジェクト機構「ジェロントロジー寄付研 究部門」が設置されました。 さらに，2009年にはその 発展形として, 東京大学「高歯社会総合研究機構 : Institute of Gerontology（IOG）」に生まれ変わりました。こ れの組織は, 総長室総括委員会の直下に位置付けされる 学部横断型研究組織であります.

この東京大学高齢社会総合研究機構は, 通称「ジェロ ントロジー研究機構」と言われておりますが, ジェロン トロジーという言葉をまだ聞きなれない方もいらっしゃ るのではないでしょうか. 実は, この言葉は造語であり, Geron（=old man お年寄り） + logy（=the study of 学 問体系)，すなわち高齢者および高齢社会全般を扱う分 野横断型（学際的）学問領域という意味になります。図 1 に示すように, 数多くの学部から若手〜中堅の研究者 が集まっております。
実際にどのような活動をしているかというと，前述し ましたように「Action Research（アクション・リサー チ：課題解決型実証研究)」を推し進めております。具体 的には，全国でいくつものモデルフィールド自治体を持 ち，その地域に転がっている課題や目指すべき将来の地 域コミュニティ像を地域の現場の方々とともに話し合 い，継続可能なモノを創り上げるというものです。すな わち,「総合的なまちづくり」を可視化したモデルとして 具現化していくことです。さらに，そのノウハウやエッ センスを世に発信しながら，次なる自治体にそれを上手 く転用していき，徐々に広域に展開できるようにしてい くのです.

筆者も老年医学の医師であり，基本的には医療機関で 働いてきている立場ですが，多種多様な住民が住んでい る地域コミュニティに視点を移してみると, 我々が専門 とする医療やへルスケアだけではなく，数多くの課題が 転がっており，それらが梁く関連していたり重複してい ることが分かってきました，図 2 に示すように，人との つながりの希薄さ，孤食，空き家問題，様々なケアの課 題（ダブルケアや介護共倒れ，介護難民，等）, 買い物 難民，待機児童問題，孤立化や引きこもり，ゴミ屋敷問 題, 8050 問題（80 歳代くらいの高龄の親を 50 歳代くら いの単身子供が同居していかなければならない事情), 等々。地域には他にももっと多くの諸問題が転がってい ます.

どのようにして「活力ある超高齢社会」を目指すこと が出来るのでしょうか. 地域在住高齢者にとって「真の 役割, 出番, 居場所」はどのようなものであり, 各地域 でどのように準備すれば良いのでしょうか. また，そこ には行政，専門職能，民間事業者，住民など，地域を構 

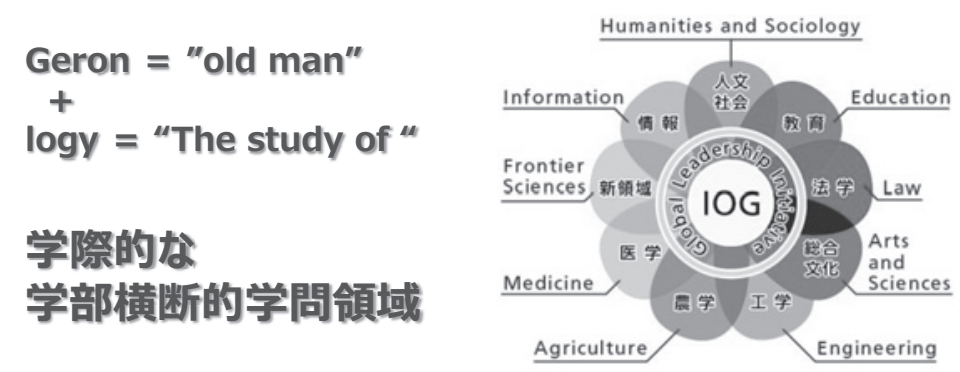

\section{Action Research (アクション・リサーチ) 課題解决型実証研究 \\ $\Rightarrow$ 継続可能なモノを創り上げる $\Rightarrow$ 「総合的なまちづくり」を可視化したモデルとして具現化}

図 1 Gerontology ジェロントロジー（総合老年学）

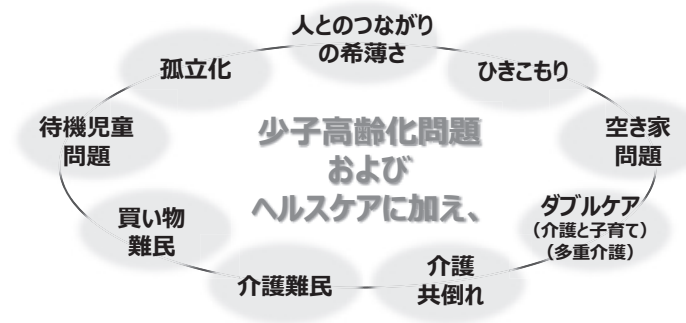

$\checkmark$ 高齢者にとつて、「役割」「出番」「居場所」のある地域とは、、

$\checkmark$ 行政、専門職能、民間事業者、住民等が行動原理の違いを乗り 越え、地域課題を協働して解決する関係性を備えた地域とは、.

図 2 抱えている多くの課題とその重複

成している方々は行動原理が違う集団が混在しており, 実は同じ価值観になり難い背景があります。その行動原 理の違いを乗り越え, 地域課題を協働して解決していけ る関係性をどのように構築できるのでしょうか. 実は, このアクションリサーチは究極の社会介入実験ですの で，時間とかなりの労力がかかるのですが，逆に，少し ずつ地域が変わってきていることも分かりますし，根付 く活動に繋がりますので, 非常にダイナミックな取り組 みです。

さて, 我々のアクションリサーチをもっと具体的にご 紹介しましょう。基幹研究として推し進めているものを 簡単なイメージ図として, 図 3 で示します。

活力ある超高齢社会を実現するために，基本 3 要素と して以下を揭げております。

(1)健康自立寿命を最大化する地域生活環境の整備
(Healthy Ageing),

(2)最期まで地域で暮らせるケアシステムと地域生活環 境の整備 (Ageing in Place),

(3)高齢者も働き活動し社会に貢献できる地域生活環境 の整備 (Social Inclusion)

以上の目標を達成するため, 本機構は以下の 4 つの共 創的アプローチを重視し，推し進めております.

1）分野横断的共創チームによる取り組み

2）地域共創型アクションリサーチを通じた実践的・ 実効性な知の共創と体系化

3）産官学民連携の取り組みを通じた社会の真のニー ズに応えるソリューションの共創

4）国際連携型教育研究を通じたグローバルな施策の 共創と推進

さらに具体的なアクションリサーチの内容を列挙しま すと, 以下のようなものがあります.

○フレイル予防のための大規模高齢者研究, および 標準プログラムの開発と全国展開

○次世代地域包括ケアシステムの標準モデル構築と その体系的マニュアルの策定

多職種連携体制の標準モデルの開発と水平展開

高齢者の社会参加・社会活動・就業機会を増進す る仕組の開発と施策化

安全安心住環境：〜弱らない・弱っても暮らし続 けられる住環境デザイン〜

高齢者の転倒/骨折の実態分析による予防対策・ 事後対策の検討 


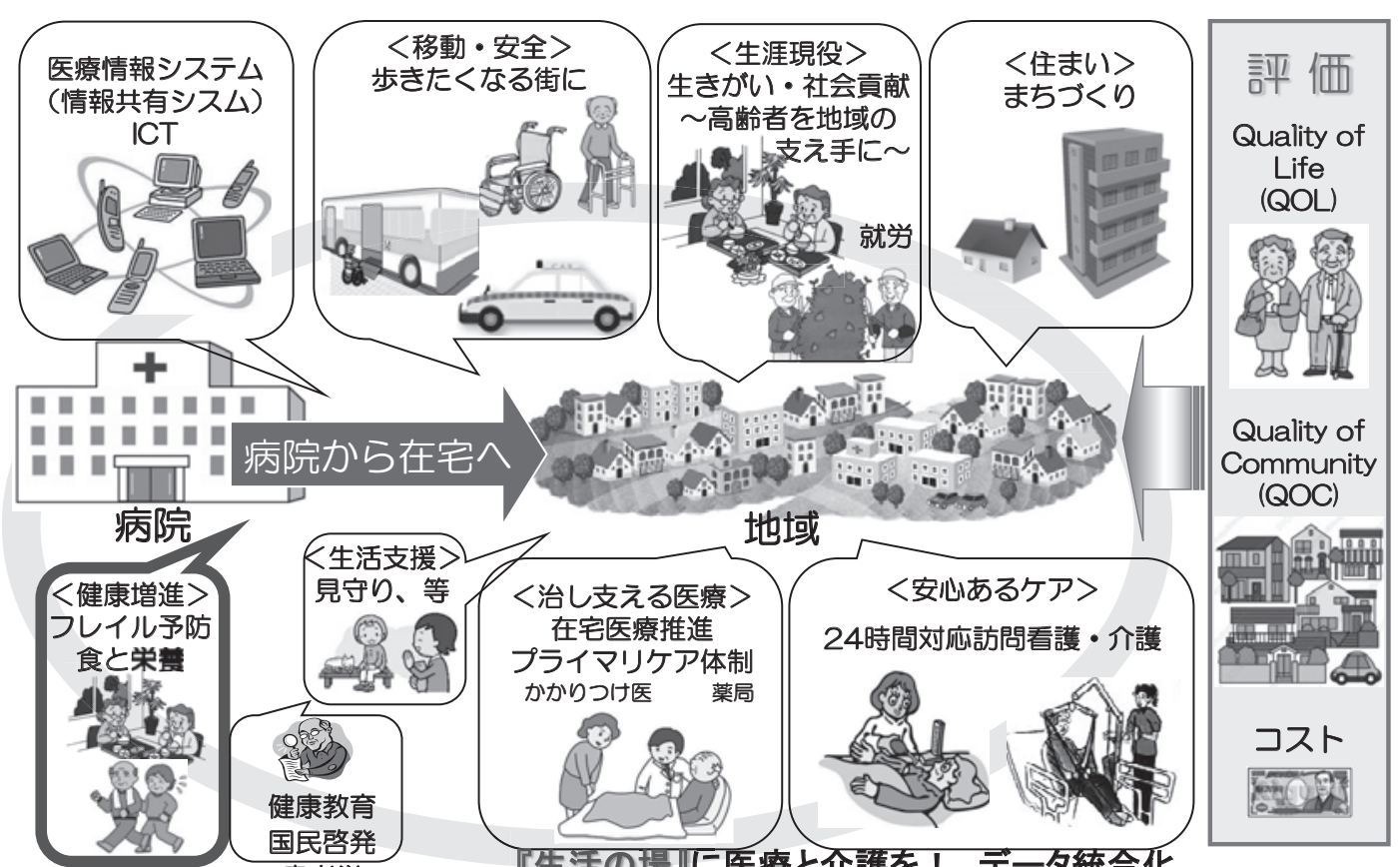

東京大学高齢社会総合研究機構 (IOG)資料 : 飯島勝矢により改变

図 3 我々のアクション・リサーチ：『Aging in Place』 住み慣れた場所で安心して自分らしく

(1) 大規模高齢者 長期縦断追跡コホート研究

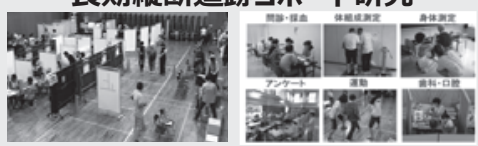

【悉皆調查】地域診断

【エビデンス】

三位一体の重要性

（食/口腔·運動·社会参加） 【アクションリサーチ】 エビデンスを地域へ 産官学民を巻き込む

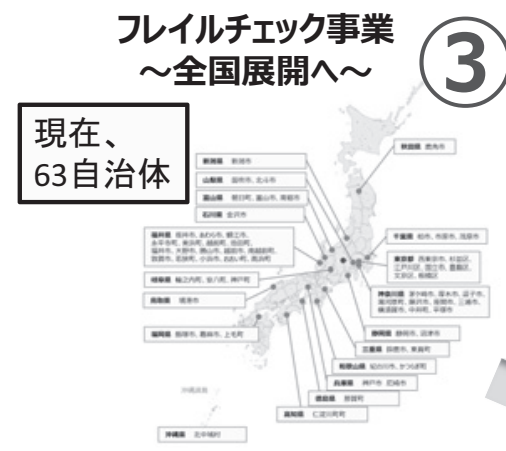

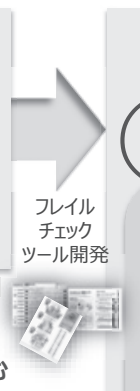

市民主体(フレイルサポーター)による栄養・運動・ 社会参加を軸とする包括的フレイルチェック

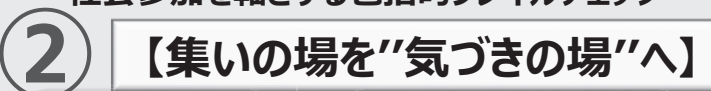

自治体との協働による フレイルサポーター養成
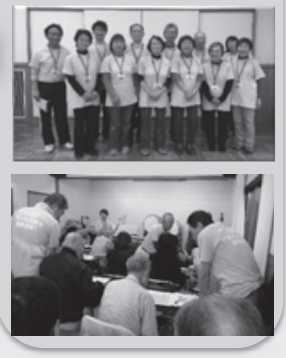

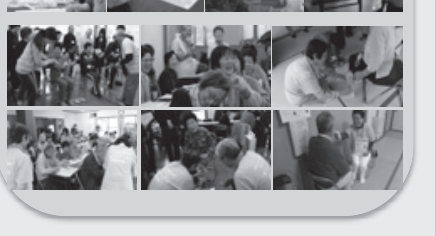

養成研修後、地域の集いの場へ 皆でワイワイと、フレイル兆候に気づく

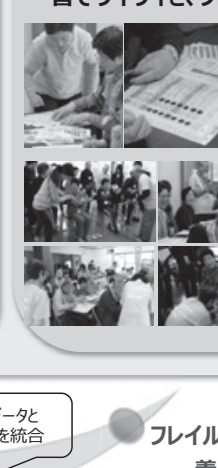

フレイルトレーナー/サポーター 養成システムの確立

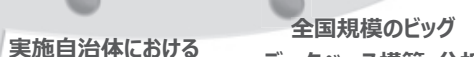
健康長寿のまちづくりへの参画 データベース構築·分析

(4) 全国のフレイルチエツクによる【データベース】

図 4 フレイル予防を通した健康長寿のまちづくり 


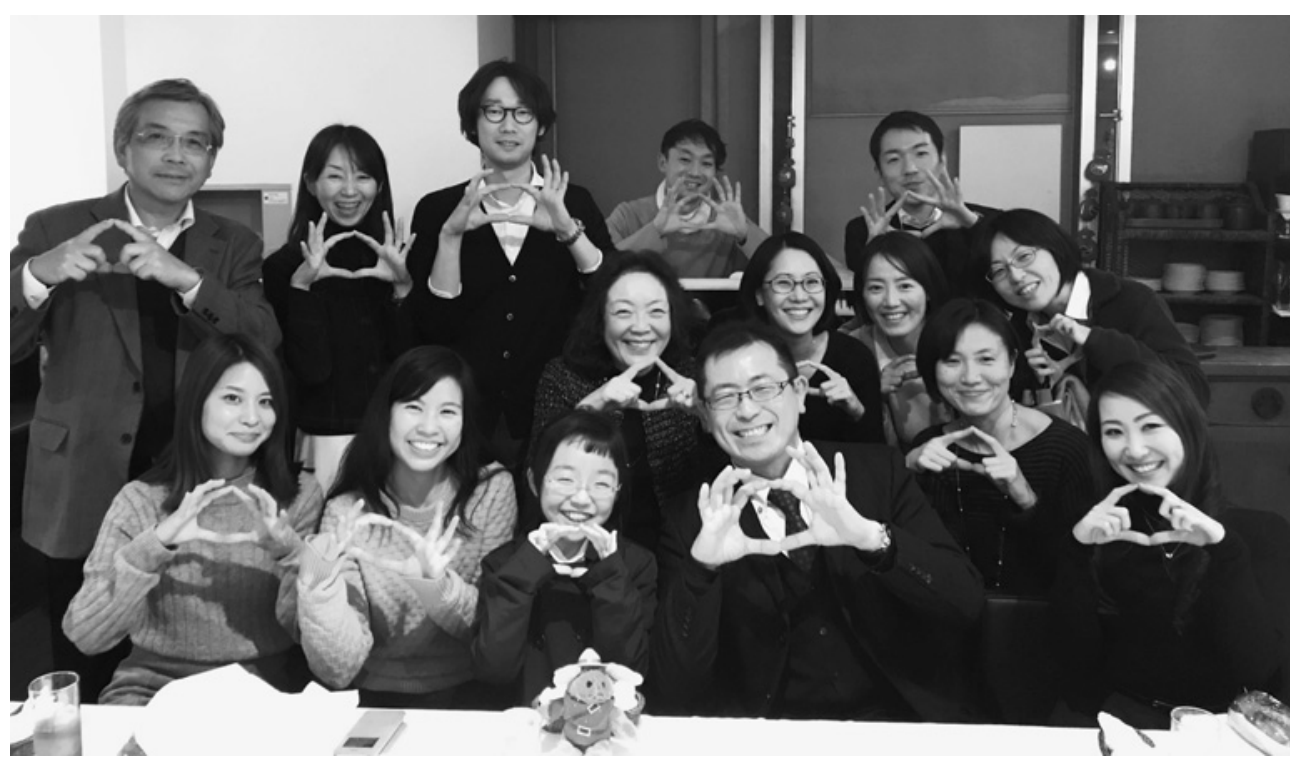

図 5 東京大学 高齢社会総合研究機構 (ジェロントロジー: 総合老年学) フレイル予防研究チーム メンバー

(忘年会風景の写真より)

地域活動の住民主体的展開を推進するプログラム の研究開発

○住民主体の包括的コミュニティづくりのプロセス デザイン（住民自身による地域課題の発見・課題 解決方策の策定・活動展開)

超高齢社会の物的・社会的生活インフラ, 日常生 活圈空間構成の標準モデルの研究開発

高齢者生活支援技術（GeronTechnology：Assistive Technology）の研究開発

○インラクティブ AI による見まもり・生活アテ ンドシステム

○同時に, 産学連携共同研究（ジェロントロジー・ ネットワークを構築), なかでも (オープンパブ リックな）高齢社会共創プラットフォーム/リビ ングラボ・ネットワーク

これら多面的な研究活動を通し，下記のようなデザイ ンを組んでおります。

【1】(医学・生命系) エイジングのメカニズムの解明を 踏まえた，高齢者の健康維持と QOL 向上のためのライ フスタイルとケアサポートシステムのデザイン

【2】(人文・社会科学系) 健康寿命を最大化し, 在宅介 護生活を支え, 社会参加を促進する, 地域社会の生活環 境とアクティビティのデザイン
【3】(工学・情報理工学系) 次世代ジェロンテクノロ ジー/アシスティブテクノロジーの開発と支援的生活環 境・移動環境のデザイン

なかでも，上記の一覧に入っている「フレイル予防の ための大規模高齢者研究，および標準プログラムの開発 と全国展開」に関して, 図 4 で補足説明いたします。

地域在住高齢者を対象として, 大規模縦断追跡調査研 究を経年的に継続しており, 多面的なフレイルの視点に 立った幅広い調查を行っております。そこからの科学的 根拠（エビデンス）を活用し，全国の各自治体に必ず存 在する公民館や地域サロン等の高齢者の集いの場で展開 していく「高齢住民主体のフレイルチェック活動を通し た健康長寿のまちづくり」事業が全国で多くの自治体に 導入して下さり, 走っております。 これは, 地域の元気 シニアに養成研修を受けた後に「フレイルサポーター」 になってもらい，彼ら主導で高齢者同士だけでのフレイ ルチェックを展開していくものです。このチェックによ り, フレイル予防のための 3 つの柱（栄養・運動・社会 参加）の重要性を気づき, 自分事として捉え, 意識変容〜 行動変容していくものです，現在のところ，全国で 63 自治体が導入し，精力的に実施してくれております。こ のチェックは単会で終わらず, 必ず継続的に参加するよ うにとの工夫がされており，その収集されてきたデー夕 
ベースが定期的にコントロールセンターであるわれわれ 東京大学のフレイル予防研究チームに集約される仕組み になっております（図 5 に集合写真を揭載します）。

さらに, 国際共創活動として, 高齢社会研究教育拠点 の国際ネットワーク形成のために, IARU (International Alliance of Research Universities: 国際研究型大学連 合）にも加盟しております. 東京大学以外の他の加盟大 学（オーストラリア国立大学 (ANU), シンガポール国 立大学 (NUS), 北京大学, スイス連邦工科大学チュー リッヒ (ETHZ), カリフォルニア大学バークレー校, ケンブリッジ大学, オックスフォード大学, イェール大 学, コペンハーゲン大学, ケープタウン大学) とともに,
計 11 校で構成し, 様々な分野の研究や教育のことを話 し合っております。

さいごに,

日本をフロントランナーとして世界で急速に進行する 社会の高齢化にともなう諸問題を解決するため, 我々 ジェロントロジー研究機構は東京大学内および国内外の 関係研究者・行政・専門職・産業界・市民, いわゆる産 学官民の総力を結集する国際的研究拠点を形成したいと 思っております。そして, 今まで培ってきました高齢化 課題解決に向けた「知」をさらに社会に循環させていき たいと願っております。 